\title{
A strategic defeat of Populism in Greece.
}

\author{
Mavrozacharakis , Emmannouil
}

Phd. Candidate, Faculty of Political Science University of Crete, Researcher of Centre of Human Rights in the Faculty of Political Science University of Crete

\begin{abstract}
The recent elections in Greece reflects an enormous change in the political behavior of the electorate. The citizens have not chosen a simple switch on the power, but contributed with their votes to a strategic defeat of populism and in same time they paved the way for the search of a new type of leadership, which is close to realism in handling with social problems that can't be implemented with calculated financial costs. The vote of 7 th Juli is a vote against the over-promising and underdelivery experienced under Syriza's rule. The voting for conservative ND is not an ideological choice. It's a choice that runs counter to the logic of falsely or hypocritical negotiating austerity measures opposed to Greece buy his Lenders (memorandum) and the consequent tax-tornado as a result of negotiating failure with the partners in the EEC and the IMF. The positive vote for ND also reflects the contradiction with the misguided manipulations of public opinion regarding the Skopje-Question and finally the strategy of micro concessions and micro- allowances as a means of concluding a "political-social alliance" with an undefined hostile establishment.
\end{abstract}


It is clear that strategic electoral defeats do not refer to percentages, but to structural transformations and shifts in the electorate and to voting against political logics. In these sense the recent elections in Greece reflects an enormous change in the political behavior of the electorate. The citizens have not chosen a simple switch on the power, but contributed with their votes to a strategic defeat of populism and in same time they paved the way for the search of a new type of leadership, which is close to realism in handling with social problems that can't be implemented with calculated financial costs. The vote of 7 th Juli is a vote against the over-promising and under-delivery experienced under Syriza's rule. In this terms "Greece already has first-hand experience of economic populism and is now rejecting it, making a turn towards pragmatism", as Pagoulatos states( Lana-Guggenheim:2019) “"The vote in 2015 was one of hope, of desperation. Then the idealism collapsed. Now people are focusing on who they believe can deliver (Lana-Guggenheim:2019).

According to Kazamias (2019) the main reason of the defeat of Syriza is weather his stance according the Name of Skopje (Prespa Agreement) nor the rejection of Syrizas populism. For Kazamias (2019) « The painful truth about Syriza is that it has ruled Greece for four years as a party suffering from identity loss and diminishing credibility. Its record in government has been so full of compromises and retreats that it now hovers across the political spectrum like an amorphous haze $-\mathrm{a}$ phantom of its old self, without much shape or substance. Tsipras's cabinet includes ministers who have defected from almost every other party in parliament, even several hard-right populists from the Independent Greeks»».

This view is not without truth, but it does not take into account that the populism of the Greek Syriza, in material, political, and symbolic way, are typically participatory and inclusive by attempting to promote political programs that improve in some way the quality of life of some weak and poor social groups and migrants (Font/ Graziano/ Tsakatika: 2019). In a sense, the left-wing populism of Syriza follows the Latin American model of populism that deals with societies that do not have the level of equalization and prosperity of Western Europe (Mavrozacharakis:2018,30).

This does not mean that there are no acute socio-economic differences in Western Europe as well. However, the weakest social groups still rely on more or less extensive social services and aids and enjoy full political right. Like the populists in Latin America, who are struggling for better living conditions of the population 
(Mudde \& Kaltwasser:2013, 159), left-wing populism of Syriza also behaves more explicitly about the excluded, the marginalized and the underprivileged (Mavrozacharakis:2018,30). However, the political and economic reality that surrounds Greece left no room for the realization of populism as it was anticipated by the ruling left in Greece.

The voting for conservative ND is not an ideological choice. It's a choice that runs counter to the logic of falsely or hypocritical negotiating austerity measures opposed to Greece buy his Lenders (memorandum) and the consequent tax-tornado as a result of negotiating failure with the partners in the EEC and the IMF. Unable to beat the creditors of Greece, the Syriza-Government joined them, «implementing all the cuts, privatizations, and VAT increases it had been elected to oppose». (Younge:2019). Alexis Tsipras agreed with the Eurozone partners and lenders to implement one of the harshest austerity programs. At the same time though, and with a strong populist manner, Tsipras government attempts to distance itself from the verbal content of the austerity measures it has negotiated and voted (Mavrozacharakis/Kotroyannos/ Tzagkarakis:2017,41).

The SYRIZA government relieve communicatively that it has the ability to move flexibly within a tight framework. In reality though, SYRIZA not only failed to fulfil its campaign promises but also to implement even a part of its core ideological principles (Mavrozacharakis/Kotroyannos/Tzagkarakis:2017,41).

Moreover, the left unwittingly turned to realism as its anti-memorandum negotiating strategies were totally failed. However, electorally, the leading group of SYRIZA is still able to extract the majority of social acceptance despite the implementation of the new memorandum. This fact just proves the effectiveness of populism that Tsipras government uses. The road that led to the final compromise of SYRIZA government with lenders was marked by the symbolic production of politics in the sense that a continuous hard negotiation scenario with the partners was raised, as a "race-till-you-drop" to avoid the memorandum. Similarly, the left government after signing the Memorandum, tried to cultivate the impression that it will do everything to normalize its social effects. The radical fury with which SYRIZA demonized the memorandum and everyone who was involved in its managements in Greece and abroad, while the party was in opposition(Petras: 2015), was followed during its first governmental period by a managerial modesty of subordination to the partners. It is to note, that since 2016 the income taxes are especially harsh on people 
earning more than 35,000 euros per year, as they pay an average of 40 percent more than they did before. If we add the rise in higher social security dues, the increase comes to 70 percent. This is likely to lead to even more people being unable to pay taxes and social security contributions. In addition to the income tax, the amount that people will have to pay for the ENFIA property ownership tax is about 3.4 billion euros yearly. However, many people are unable to pay. It is therefore understandable the anger of the citizens against a government that before the elections promised social redemption.

As a result of all this in the meantime, the evaluation of the causes of the crisis has shifted in the voters' opinion. People no longer believe in the hostile image of Europe as the left projected it before the 2015 elections. Brussels - and Berlin - are no longer so much blamed for the crisis, but the fight for the best economic model for Greece in the coming years has come more into focus (Löhe:2019). And here Syriza and the reawakened Nea Dimokratia are clearly distinguishable. Some want higher pensions and higher social spending, others lower taxes and lower free market limits. These are quite domestic reasons, and they have led to Tsipras' defeat. Nevertheless, the election victory of the Conservatives gives a hint for the whole of Europe. The large-scale narrative of the populists that they are the traditional parties that had destroyed the respective country no longer works. With the example of Greece, arrogance becomes clear: In negotiations with the EU, not everything can be achieved - except a compromise (Löhe:2019).

The positive vote for ND also reflects the contradiction with the misguided manipulations of public opinion regarding the Skopje-Question and finally the strategy of micro concessions and micro- allowances as a means of concluding a "political-social alliance" with an undefined hostile establishment. The overall strategy chosen by SYRIZA for the governance of the country was therefore defeated. At the same time, however, it is inappropriate to attempt to interpret the results of the national elections in Greece on the basis of the results of the European elections. In the European elections there was a factor of loose voting, reduced polarization and disorientation due to parallel municipal-regional elections. The vote of the European elections was more punitive in the sense of a sanctioning choice because of the FYROM-Question and the austerity politics (memorandum), and it acted as a warning and an outlet or emotional release for peoples political anger, underlining in a sense the demand for a shift towards more social policies and less taxation (Stevis- 
Gridneff:2019). Under the polarizing conditions of national elections the terms were completely different and many is forgiven because of the self-criticism (Kadrizke:2019) and above all the expression of "repentance" shown by the rulers. A great role once again played the persuasiveness in the Mea Culpa!.

Moreover should be taken into account, that the provision of Greek citizenship to thousands of immigrants and the introduction of voting right in the 17 , favors the SYRIZA Party. For this reason, there is no justification for the sizzling leadership of Syriza, which believes it has not suffered a strategic defeat in the national elections, holding more than 30\% (see for example: Tzanakopoulos :2019). However, in the political map of Greece, there have been strategic changes and, indeed, seismic. First of all, the citizens did not give a vote of confidence to the Syriza government and the "financial relief measures" it received (Karitsis:2016).

These measures constituted a strategic choice of SYRIZA that was defeated. In particular was misplaced, the political extortion of the economically weaker voters, arguing by Left proponents, that in the event of ND victory the crumbs preemptively distributed by Syriza would be in jeopardy. Also, the mobilization of the anti-rightwing syndrome of the left and centrist voters, slamming the "bogey" of the "evil" right, failed. Above all, however, there has been neutralized the catch-all ability of Syriza to penetrate into all social strata numerous civil society organizations and above all, the middle strata, which have now been convinced by the narrative about ND's tax exemption (Adler:2019). The strategic political tool with a few words of populism based on enemy-friend shapes (Mavrozacharakis/Tzagkarakis/ Kamekis: 2015,2) was canceled and his position got a more realistic depiction of the reality expressed by the right of Kyriacos Mitsotakis.

For that reason, $\mathrm{CNN}$, commenting on the election results in Greece, pointed out that the election of ND to power was the end of left-wing populism in the sense that it was a vote of protest against a government that promised too much while it did very little (Labropoulou 2019). Despite the fact that CNN points out that the new government of ND appears to have plans for reforms, Mitsotakis comes from the same political establishment that plunged Greece into the crisis and which the voters rejected in 2015. The positive vote for the market-friendly old guard is a vote of protest against a government that has given many promises, which it has failed to observe, a message to the populists worldwide that things can change and then change again. At the same time, the BBC considers voters turning their back on SYRIZA 
after adopting tough fiscal measures (BBC:2019). While in 2015 Alexis Tsipras was the personification of change, the BBC points out, he has given many promises, and under the pressure of the EU he was forced to make a turning of 180 degrees.

The German newspaper Stuttgarter Nachrichten (2019) estimates Alexis Tsipras tried to entice the voters with clumsy last-minute pre-election prizes, pays bonuses and promised increases in pensions. But even in Greece, the seasons that resulted in such tribulations have come to pass. The outcome of the elections in Greece is above all a clear rejection of populism. This is their essential importance not only for Greece but also for the whole of Europe. Why is the Tsipras now punished? Questions the German Sueddeutche Zeitung and points out that the fact that New Democracy has made such a clear victory shows that many people would like to leave behind the years of the crisis and that they want again something like regularity(Schlötzer:2019). According to the newspaper, the fact that Alexis Tsipras is punished has a lot to do with the dissatisfaction gathered during the long years of austerity, which turned the everyday life of many Greeks into a lasting struggle for survival. In conclusion, all SYRIZA's strategic political choices have been defeated, which is overshadowed by many election polls that deliberately cultivated the impression that the difference between SW and SYRIZA will exceed $12 \%$. This gave the SYRIZA leadership the opportunity to mitigate the big defeat it suffered after just 4 years of government. With an autonomous Nea Dimokratia of $40 \%$ and an $8 \%$ distance from SYRIZA, the quantitative defeat is as much as the strategic Defeat. Surely, based on the low expectation logic that remains embedded in the DNA of the left, $32 \%$ is impressive. However, since all the state power and its corresponding resources have been used to achieve this percentage, its future preservation is not relevant. In this sense, this logic is beyond the limits of power, and this is indeed a strategic defeat.

\section{References}

Adler, D (2019): The three mistakes behind Syriza's demise in Greece

Available at: https://www.theguardian.com/commentisfree/2019/jul/08/syrizademise-greece-alexis-tsipras (Accessed: 16/07/2019) 
BBC (2019) : Greek elections: Mitsotakis promises change after New Democracy win. Available at: https://www.bbc.com/news/world-europe-48905406 (Accessed: 10/07/2019)

Font, N., Graziano, P. and Tsakatika, M. (2019) Varieties of inclusionary populism? SYRIZA, Podemos and the Five Star Movement. Government and Opposition,(doi:10.1017/gov.2019.17) Available at: http://eprints.gla.ac.uk/184538/7/184538.pdf (Accessed: 16/07/2019)

Karitzis, A(2016): The 'SYRIZA Experience': Lessons and Adaptations Available at: https://socialistproject.ca/2016/03/b1236/ (Accessed: 10 /07/2019)

Kadrizke, N (2019): Neuer Wein in alten Schläuchen?

Available at: https://monde-diplomatique.de/shop content.php?coID=100143 (Accessed: 12/07/2019)

Kazamias, A (2019): Syriza betrayed its principles - and the Greek people. Its days are numbered. Available at: https://www.theguardian.com/commentisfree/2019/jul/05/syriza-greek-alexistsipras-eu-imposed-austerity-polls (Accessed: 16/07/2019)

Labropoulou, E (2019) : Greek elections: Victory for New Democracy party signals end of left-wing populism

Available at: https://edition.cnn.com/2019/07/07/europe/greece-elections-newdemocracy-intl/index.html (Accessed: 19/7/2019)

Lana-Guggenheim, B (2019): Marking the End of an Era, Syriza Loses to New Democracy in a Landslide. Available at: https://www.southeusummit.com/europe/greece/marking-the-end-of-an-erasyriza-loses-to-new-democracy-in-a-landslide/ (Accesed:17/07/2019)

Löhe, F (2019): Tsipras' Niederlage als WendepunktDer Populismus in Europa könnte seinen Zenit überschritten haben. Available at: https://www.tagesspiegel.de/politik/tsipras-niederlage-als-wendepunkt-derpopulismus-in-europa-koennte-seinen-zenit-ueberschritten-haben/24535808.html (Accessed:15/07/2019) 
Mavrozacharakis, E/ Tzagarakis, S/ Kamekis, A (2015) . "Modern Populism in Greece," MPRA Paper 62656, University Library of Munich, Germany.Handle: RePEc:pra:mprapa:62656

Mavrozacharakis, E., Kotroyannos, D., \& Tzagkarakis, S. I. (2017). Mediterranean Left-Wing Populism: The Case of SYRIZA. European Quarterly of Political Attitudes and Mentalities, 6(2), 40-54. https://nbn-resolving.org/ urn:nbn:de:0168-ssoar-51522-9

Mavrozacharakis, E. (2018). Populism and Democracy: An Ambiguous Relationship. European Quarterly of Political Attitudes and Mentalities, 7(4), 1935. https://nbn-resolving.org/urn:nbn:de:0168-ssoar-59935-4

Mudde, C/ Kaltwasser, C. R. (2013): Exclusionary vs. inclusionary populism: comparing contemporary Europe and Latin America, Government and Opposition, 48, 2: S. 147 - 174.

Petras, J. (2015), Lies and Deceptions on the Left: The Politics of Self Destruction Greece, France, Brazil, Available online at: http://www.globalresearch.ca/lies-and-deceptions-on-the-left-the-politics-of-selfdestruction/5438105 (Accessed: 02/12/2015)

Schlötzer, C (2019): Warum Tsipras jetzt abgestraft wurde

Available at; https://www.sueddeutsche.de/politik/griechenland-wahl-athen$\underline{\text { mitsotakis-1.4514665 (Accessed: 10/07/2019) }}$

Stevis-Gridneff, M (2019) : Long Economic Crisis Ushers In New Leadership in Greece

Available at: $\quad$ https://www.nytimes.com/2019/07/07/world/europe/greekelections.html (Accessed: 17/07/2019) 
Stuttgarter Nachrichten (2019) : Alexis Tsipras muss gehenGriechenland wählt Konservative an die Macht

Available at: https:/www.stuttgarter-nachrichten.de/inhalt.alexis-tsipras-mussgehen-griechenland-waehlt-konservative-an-die-macht.23af6714-f113-4b2e-869d-

936ffabbc9b5.html (Accessed:10/07/2019)

Tzanakopoulos, D (2019) : Election result 'not a strategic defeat' for SYRIZA

Available at: https://www.tovima.gr/2019/05/26/international/tzanakopouloselection-result-not-a-strategic-defeat-for-syriza/

(Accessed: 16/07/2019)

Younge, G (2019): Syriza's defeat shows the left needs a plan to hold on to power, not just win it. Available at :https://www.theguardian.com/commentisfree/2019/jul/12/syriza-left-election

(Accessed: 15/07/2019) 